\title{
Open System Re-Os Isotope Behavior in Platinum-Group Minerals during Laterization?
}

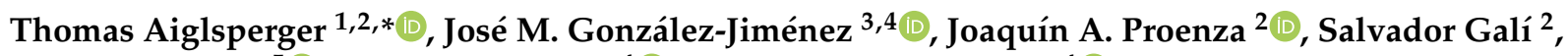 \\ Francisco Longo ${ }^{5}\left(\mathbb{D}\right.$, William L. Griffin ${ }^{4}(\mathbb{D})$ and Suzanne Y. $^{\prime}$ 'Reilly ${ }^{4}(\mathbb{C}$
}

1 Division of Geosciences and Environmental Engineering, Department of Civil Engineering and Natural Resources, Luleå University of Technology, SE 97187 Luleå, Sweden

2 Departament de Mineralogia, Petrologia i Geologia Aplicada, Universitat de Barcelona (UB), Martí i Franquès s/n, 08028 Barcelona, Spain; japroenza@ub.edu (J.A.P.); gali@ub.edu (S.G.)

3 Departamento de Mineralogía y Petrología, Facultad de Ciencias, Universidad de Granada, Avda. Fuentenueva s/n, 18002 Granada, Spain; jmgonzj@ugr.es

4 ARC Centre of Excellence for Core to Crust Fluid Systems (CCFS) and GEMOC National Key Centre, Macquarie University, Sydney, NSW 2109, Australia; bill.griffin@mq.edu.au (W.L.G.); sue.oreilly@mq.edu.au (S.Y.O.)

5 Faculty of Engineering, Universidad Catolica Tecnologica del Cibao (UCATECI), Ave. Universitaria, esq. Ave. Pedro Rivera, La Vega P.O. Box 401, Dominican Republic; longof@claro.net.do

* Correspondence: thomas.aiglsperger@ltu.se; Tel.: +46-724520643

Citation: Aiglsperger, T.;

González-Jiménez, J.M.; Proenza, J.A.;

Galí, S.; Longo, F.; Griffin, W.L.;

O'Reilly, S.Y. Open System Re-Os

Isotope Behavior in Platinum-Group

Minerals during Laterization?

Minerals 2021, 11, 1083. https://

doi.org/10.3390/min11101083

Academic Editor: Nigel J. Cook

Received: 31 December 2020

Accepted: 28 September 2021

Published: 1 October 2021

Publisher's Note: MDPI stays neutral with regard to jurisdictional claims in published maps and institutional affiliations.

Copyright: (c) 2021 by the authors. Licensee MDPI, Basel, Switzerland. This article is an open access article distributed under the terms and conditions of the Creative Commons Attribution (CC BY) license (https:// creativecommons.org/licenses/by/ $4.0 /)$.

\begin{abstract}
In this short communication, we present preliminary data on the Re-Os isotopic systematics of platinum-group minerals (PGM) recovered from different horizons in the Falcondo Ni-laterite in the Dominican Republic. The results show differences in the Os-isotope composition in different populations of PGM: (i) pre-lateritic PGM yield ${ }^{187}$ Os $/{ }^{188}$ Os varying from $0.11973 \pm 0.00134$ to $0.12215 \pm 0.00005$ ( $2 \sigma$ uncertainty) whereas (ii) lateritic PGM are more radiogenic in terms of ${ }^{187} \mathrm{Os} /{ }^{188} \mathrm{Os}$ (from $0.12390 \pm 0.00001$ to $0.12645 \pm 0.00005 ; 2 \sigma$ uncertainty). We suggest that these differences reflect the opening of the Re-Os system in individual grains of PGM during lateritic weathering. The implications of these results are twofold as they will help to (1) elucidate the small-scale mobility of noble metals in the supergene setting and therefore the possible formation of PGM at these very low temperatures, (2) better refine the Os-isotopic datasets of PGM that are currently being used for defining dynamic models of core-mantle separation, crustal generation, and fundamental plate-tectonic processes such as the opening of oceans.
\end{abstract}

Keywords: Re-Os isotopes; platinum-group minerals; Ni laterite; Dominican Republic

\section{Introduction}

Among the applicable radiogenic isotopic systems, the ${ }^{187} \mathrm{Re}^{187}$ Os system is arguably one of the most sensitive tools to investigate the long-term interaction between different regions of the Earth's interior [1]. The Re-Os isotope systematics measured in situ on platinum-group minerals (PGM) from mantle-derived rocks indeed provide robust records of these processes [2,3]. However, recent studies have yielded contradictory results on the possible robustness of the Re-Os isotopic system. Thus, primary and secondary PGM identified in some metamorphosed mantle-derived rocks yield both very distinct [4] or identical [5] ${ }^{187}$ Os $/{ }^{188}$ Os ratios, suggesting that the behavior of the system may be either open or closed during post-magmatic processes. Earlier studies, using Os-rich PGM from placers adjacent to ultramafic massifs, demonstrated a marked Os-isotopic heterogeneity that was interpreted as a proof that the convective upper mantle is isotopically heterogeneous [6-10]. These interpretations are based on the idea that PGM were formed in the mantle and transferred to the supergene environment by mechanical processes alone without modification of their original Os isotopic compositions. Hence, the isotopic composition of PGM from placers is taken to represent those of the parental igneous rocks. 
However, the fact that these grains were separated from their host rocks implies that important information linked to their petrogenesis was lost. Moreover, other works based on the study of textures and chemistry of placer and lateritic PGM have suggested that Os-bearing PGM can also form in the supergene setting [11-16]. These observations raise the question of the possible open-system behavior of the Re-Os isotopic system in placer-derived PGM. In this short communication, we present the first Os-isotopic compositions of Osrich PGM recovered from laterites. We show that two populations of PGM from the Falcondo Ni-laterite in the Dominican Republic yield distinctively different ranges of Re-Os isotopic compositions. These two populations are (1) hypogene grains (preserving pristine signatures) such as magmatic grains and grains modified by serpentinization and (2) supergene grains that (trans-)formed during advanced laterization. Our results, previously presented in abstract form in [17] and without the mineralogical knowledge of today, provide compelling evidence about how the Re-Os isotopic systems of individual PGM may be disturbed during supergenic processes.

\section{Samples and Methods}

The Os-isotope compositions of 25 individual Os-rich PGM ( $\geq 10 \mu \mathrm{m})$ were measured in situ on mounted and polished thin sections as well as on polished monolayers using laser ablation multicollector inductively coupled plasma mass spectrometry (LA-MC-ICPMS) at the ARC Centre of Excellence for Core to Crust Fluid Systems/GEMOC (Macquarie University, Sydney, Australia) following the procedures described by $[4,18]$. Previously, the chemical composition of the PGM was studied via an electron probe microanalyzer (EPMA) at the Serveis Científics i Tecnòlogics, University of Barcelona, Barcelona, Spain, following the procedure described by [14]. PGM analyzed in this study were recovered using hydroseparation techniques (www.hslab-barcelona.com) (17 December 2020) from three chromitite samples (each about $3 \mathrm{~kg}$ ) collected from three Ni-laterite profiles (i.e., Loma Peguera; L.P.; at $70^{\circ} 19^{\prime} 22^{\prime \prime} \mathrm{W} 18^{\circ} 54^{\prime} 01^{\prime \prime} \mathrm{N}$; Loma Larga; L.L.; at $70^{\circ} 20^{\prime} 06^{\prime \prime} \mathrm{W} 18^{\circ} 55^{\prime} 03^{\prime \prime}$ N; Loma Caribe; L.C.; at $70^{\circ} 25^{\prime} 11^{\prime \prime} \mathrm{W} 19^{\circ} 00^{\prime} 16^{\prime \prime} \mathrm{N}$ ) of the Falcondo mining area in the Dominican Republic, which is the largest hydrous Mg silicate-type Ni laterite deposit in the Greater Antilles [14-16]. This weathering profile was developed on serpentinized ophiolite-related ultramafic rocks (mainly harzburgite) and consists of a thick saprolite horizon topped by a Fe oxide(s)-dominated limonitic cover [14,19-21].

The analyzed grains include the two different types of PGM identified within the lateritic profiles [14-16] (Figure 1): (1) high-temperature magmatic PGM preserving their pristine textural signatures (e.g., laurite included in chromite) or intermediate-temperature PGM produced by reworking of the former during serpentinization (hereafter pre-lateritic PGM), (2) ruthenian hexaferrum $\left(\mathrm{Ru}_{0.4}(\mathrm{Os}, \mathrm{Ir})_{0.1} \mathrm{Fe}_{0.5}\right)$ and intermediate $\mathrm{Ru}-\mathrm{Os}-\mathrm{Fe}$ alloys with microchannels of Fe-oxide(s), which formed by continuous alteration of the former PGM during laterization as described in detail in [16] (hereafter lateritic PGM). Pre-lateritic PGM are associated with small chromitite pods (2-5 m long) embedded in the saprolite (L.P. and L.C.). They occur in heavy mineral concentrates either as discrete free grains or as inclusions in Cr-spinel. Pre-lateritic PGM include laurite $\left(\mathrm{RuS}_{2}\right)$-erlichmanite $\left(\mathrm{OsS}_{2}\right)$, Os-Ir-(Fe) and Ru-Os intergrown with Mg-Si (Figure 1; Table 1). Lateritic PGM were found in a so-called "floating chromitite" within limonite at L.L. (above the Mg-discontinuity where $\mathrm{Mg}$ is significantly depleted) and at L.P. in the same chromitite sample hosting the pre-lateritic PGM in saprolite (below the Mg-discontinuity; Figure 1). Additional details on the mineralogy of these two types of PGM are provided in [14-16] whereas Re-Os data obtained in this study are provided in Table 1. 


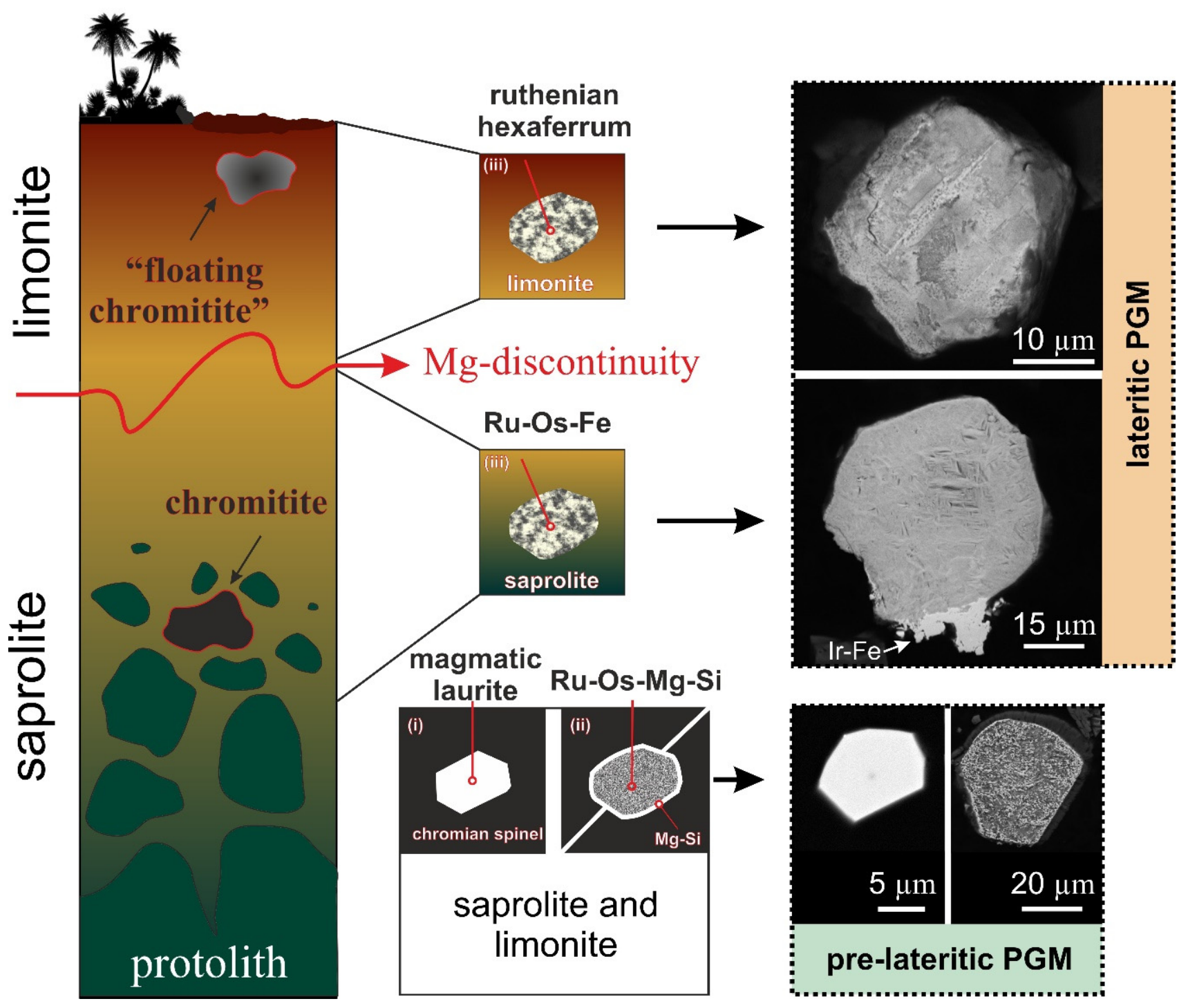

Figure 1. Sketch of a typical Ni-laterite profile of the Falcondo mining area in the Dominican Republic showing the genetic relationship between Ni-laterite formation (protolith to saprolite to limonite) and PGM transformation (magmatic laurite to Ru-Os alloy intergrown with Mg-silicates, both pre-lateritic in origin, to Ru-Os-Fe and final ruthenian hexaferrum, both lateritic in origin). Examples of typical pre-lateritic and lateritic PGM are shown as back-scattered electron (BSE) images. For details see [16].

\section{Results}

As a whole, pre-lateritic and lateritic PGM from the Falcondo Ni laterite yield low ${ }^{187} \mathrm{Os} /{ }^{188} \mathrm{Os}$ (from $0.11973 \pm 0.00134$ to $0.12645 \pm 0.00005 ;$ avg. $0.12425 \pm 0.00019 ; 2 \sigma$ uncertainty) and ${ }^{187} \mathrm{Re} /{ }^{188} \mathrm{Os}<0.0011$ (Figure 2; Table 1). PGM of magmatic origin formed at high temperature from melts (laurite-erlichmanite and Os-Ir alloy) or affected by serpentinization ( $\mathrm{Ru}-\mathrm{Os}$ intergrown with $\mathrm{Mg}$-Si) yield similar ${ }^{187} \mathrm{Os} /{ }^{188} \mathrm{Os}$ ratios varying from $0.11973 \pm 0.00134$ to $0.12215 \pm 0.00005$ ( $2 \sigma$ uncertainty) (Figure 2; Table 1$)$. In contrast, lateritic PGM consisting of Ru-Os-Fe and ruthenian hexaferrum (average Os content 20 wt.\%) with Fe-oxide(s) microchannels are more radiogenic in terms of ${ }^{187} \mathrm{Os} /{ }^{188} \mathrm{Os}$ (from $0.12390 \pm 0.00001$ to $0.12645 \pm 0.00005 ; 2 \sigma$ uncertainty). 
Table 1. In situ LA-MC-ICPMS Re-Os data of lateritic and pre-lateritic PGM from Ni-laterites in the Dominican Republic. L.L. = Loma Larga, floating chromitite, limonite; L.P. = Loma Peguera, chromitite, saprolite; L.C. = Loma Caribe, chromitite, saprolite; -53 and $-40 \mu \mathrm{m}$ size fractions; m.l. = monolayer; p.s. = polished section.

\begin{tabular}{|c|c|c|c|c|c|c|c|}
\hline PGM Grain & Notes & ${ }^{187} \mathrm{Os} /{ }^{188} \mathrm{Os}$ & $\begin{array}{l}\text { Uncertainty } \\
(2 \sigma)\end{array}$ & ${ }^{187} \mathrm{Re} /{ }^{188} \mathrm{Os}$ & $\begin{array}{l}\text { Uncertainty } \\
(2 \sigma)\end{array}$ & $\begin{array}{c}T_{R D} E C R \\
\text { (Ga) }\end{array}$ & $2 \sigma(\mathrm{Ga})$ \\
\hline L.L.-53m.1._A_1 ${ }^{1}$ & $\begin{array}{l}\text { ruthenian } \\
\text { hexaferrum and } \\
\text { Ru-Os-Fe } \\
\text { ruthenian }\end{array}$ & 0.12561 & 0.00058 & 0.00009 & 0.00050 & 0.35 & 0.082 \\
\hline L.L.-53m.1._A_2 ${ }^{1}$ & $\begin{array}{l}\text { hexaferrum and } \\
\text { Ru-Os-Fe } \\
\text { ruthenian }\end{array}$ & 0.12536 & 0.00004 & 0.00015 & 0.00002 & 0.39 & 0.005 \\
\hline L.L.-53m.1._A_3 ${ }^{1}$ & $\begin{array}{l}\text { hexaferrum and } \\
\text { Ru-Os-Fe } \\
\text { ruthenian }\end{array}$ & 0.12524 & 0.00003 & 0.00021 & 0.00002 & 0.41 & 0.004 \\
\hline L.L.-53m.1._A_4 ${ }^{1}$ & $\begin{array}{l}\text { hexaferrum and } \\
\text { Ru-Os-Fe } \\
\text { ruthenian }\end{array}$ & 0.12586 & 0.00006 & 0.00007 & 0.00002 & 0.32 & 0.009 \\
\hline L.L.-53m.1._A_5 ${ }^{1}$ & $\begin{array}{l}\text { hexaferrum and } \\
\text { Ru-Os-Fe } \\
\text { ruthenian }\end{array}$ & 0.12461 & 0.00003 & 0.00006 & 0.00001 & 0.50 & 0.004 \\
\hline L.L.-53m.1_A_66 ${ }^{1}$ & $\begin{array}{l}\text { hexaferrum and } \\
\text { Ru-Os-Fe } \\
\text { ruthenian }\end{array}$ & 0.12609 & 0.00008 & 0.00026 & 0.00003 & 0.29 & 0.011 \\
\hline L.L.-53m.1._A_7 ${ }^{1}$ & $\begin{array}{l}\text { hexaferrum and } \\
\text { Ru-Os-Fe } \\
\text { ruthenian }\end{array}$ & 0.12502 & 0.00003 & 0.00015 & 0.00002 & 0.44 & 0.004 \\
\hline L.L.-53m.1__A_8 ${ }^{1}$ & $\begin{array}{l}\text { hexaferrum and } \\
\text { Ru-Os-Fe } \\
\text { ruthenian }\end{array}$ & 0.12547 & 0.00003 & 0.00007 & 0.00001 & 0.37 & 0.005 \\
\hline L.L.-53m.1._A_11 ${ }^{1}$ & $\begin{array}{l}\text { hexaferrum and } \\
\text { Ru-Os-Fe } \\
\text { ruthenian }\end{array}$ & 0.12393 & 0.00024 & 0.00012 & 0.00004 & 0.59 & 0.034 \\
\hline L.L.-53m.1._A_12 ${ }^{1}$ & $\begin{array}{l}\text { hexaferrum and } \\
\text { Ru-Os-Fe } \\
\text { ruthenian }\end{array}$ & 0.12503 & 0.00008 & 0.00016 & 0.00004 & 0.44 & 0.011 \\
\hline L.L.-53m.1._A_13 ${ }^{1}$ & $\begin{array}{c}\text { hexaferrum and } \\
\text { Ru-Os-Fe }\end{array}$ & 0.12436 & 0.00003 & 0.00014 & 0.00005 & 0.53 & 0.004 \\
\hline L.P.-53m.1._3 ${ }^{1}$ & $\mathrm{Ru}-\mathrm{Os}-\mathrm{Fe}$ & 0.12390 & 0.00001 & 0.00004 & 0.00001 & 0.60 & 0.002 \\
\hline L.P.-53m.1._5 ${ }^{1}$ & $\mathrm{Ru}-\mathrm{Os}-\mathrm{Fe}$ & 0.12463 & 0.00003 & 0.00028 & 0.00002 & 0.49 & 0.004 \\
\hline L.P.-53m.1._F_F_1 ${ }^{1}$ & $\mathrm{Ru}-\mathrm{Os}-\mathrm{Fe}$ & 0.12645 & 0.00005 & 0.00013 & 0.00002 & 0.23 & 0.007 \\
\hline L.P.-53m.1._F_2 ${ }^{1}$ & Ru-Os-Fe & 0.12473 & 0.00003 & 0.00004 & 0.00001 & 0.48 & 0.005 \\
\hline L.P.-53m.1._G_1 1 & $\mathrm{Ru}-\mathrm{Os}-\mathrm{Fe}$ & 0.12457 & 0.00002 & 0.00014 & 0.00002 & 0.50 & 0.003 \\
\hline L.P.-53m.1._H_1 ${ }^{1}$ & $\mathrm{Ru}-\mathrm{Os}-\mathrm{Fe}$ & 0.12462 & 0.00002 & 0.00003 & 0.00001 & 0.49 & 0.003 \\
\hline L.P.-53m.1._H_2 ${ }^{1}$ & $\mathrm{Ru}-\mathrm{Os}-\mathrm{Fe}$ & 0.12475 & 0.00005 & 0.00005 & 0.00003 & 0.48 & 0.007 \\
\hline L.P.-53m.1._M_1 1 & $\mathrm{Ru}-\mathrm{Os}-\mathrm{Fe}$ & 0.12504 & 0.00006 & 0.00010 & 0.00001 & 0.43 & 0.009 \\
\hline \multirow[t]{4}{*}{ L.P.-53m.1._M_2 ${ }^{1}$} & $\mathrm{Ru}-\mathrm{Os}-\mathrm{Fe}$ & 0.12471 & 0.00004 & 0.00006 & 0.00002 & 0.48 & 0.006 \\
\hline & MAX & 0.12645 & 0.00058 & 0.00028 & 0.00050 & 0.60 & 0.082 \\
\hline & MIN & 0.12390 & 0.00001 & 0.00003 & 0.00001 & 0.23 & 0.002 \\
\hline & AVG & 0.12500 & 0.00008 & 0.00012 & 0.00005 & 0.44 & 0.011 \\
\hline L.P.-53m.1._C_1 ${ }^{2}$ & Os-Ir-(Fe) & 0.12153 & 0.00128 & 0.00068 & 0.00050 & 0.93 & 0.180 \\
\hline L.P.-40m.1._1 ${ }^{2}$ & Ru-Os-Mg-Si & 0.12149 & 0.00034 & 0.00009 & 0.00026 & 0.94 & 0.048 \\
\hline L.C._p.s.3a_4 ${ }^{2}$ & Ru-Os-Mg-Si & 0.12142 & 0.00022 & 0.00104 & 0.00026 & 0.94 & 0.031 \\
\hline L.C._p.s.3a_7 2 & $\mathrm{Ru}-\mathrm{Os}-\mathrm{Mg}-\mathrm{Si}$ & 0.11973 & 0.00134 & 0.00016 & 0.00056 & 1.18 & 0.187 \\
\hline \multirow[t]{4}{*}{ L.P.-40m.1._2 2} & laurite & 0.12215 & 0.00005 & 0.00008 & 0.00003 & 0.84 & 0.007 \\
\hline & MAX & 0.12215 & 0.00134 & 0.00104 & 0.00056 & 1.18 & 0.187 \\
\hline & MIN & 0.11973 & 0.00005 & 0.00008 & 0.00003 & 0.84 & 0.007 \\
\hline & AVG & 0.12127 & 0.00065 & 0.00041 & 0.00032 & 0.97 & 0.090 \\
\hline
\end{tabular}

lateritic PGM; ${ }^{2}$ pre-lateritic PGM; model ages have been calculated relative to the Os-isotope evolution of Enstatite Chondrites (present day ${ }^{187}$ Os $/{ }^{188} \mathrm{Os}$ $\left.=0.1281,{ }^{187} \mathrm{Re} /{ }^{188} \mathrm{Os}=0.421,[22]\right)$.

The calculated rhenium-depleted model ages $\left(\mathrm{T}_{\mathrm{RD}}\right)$ for the above described grains fall in two groups: pre-lateritic PGM cluster around $\sim 0.9 \mathrm{Ga}$, lateritic PGM cluster around $\sim 0.5 \mathrm{Ga}$ (Figure 3; Table 1). 


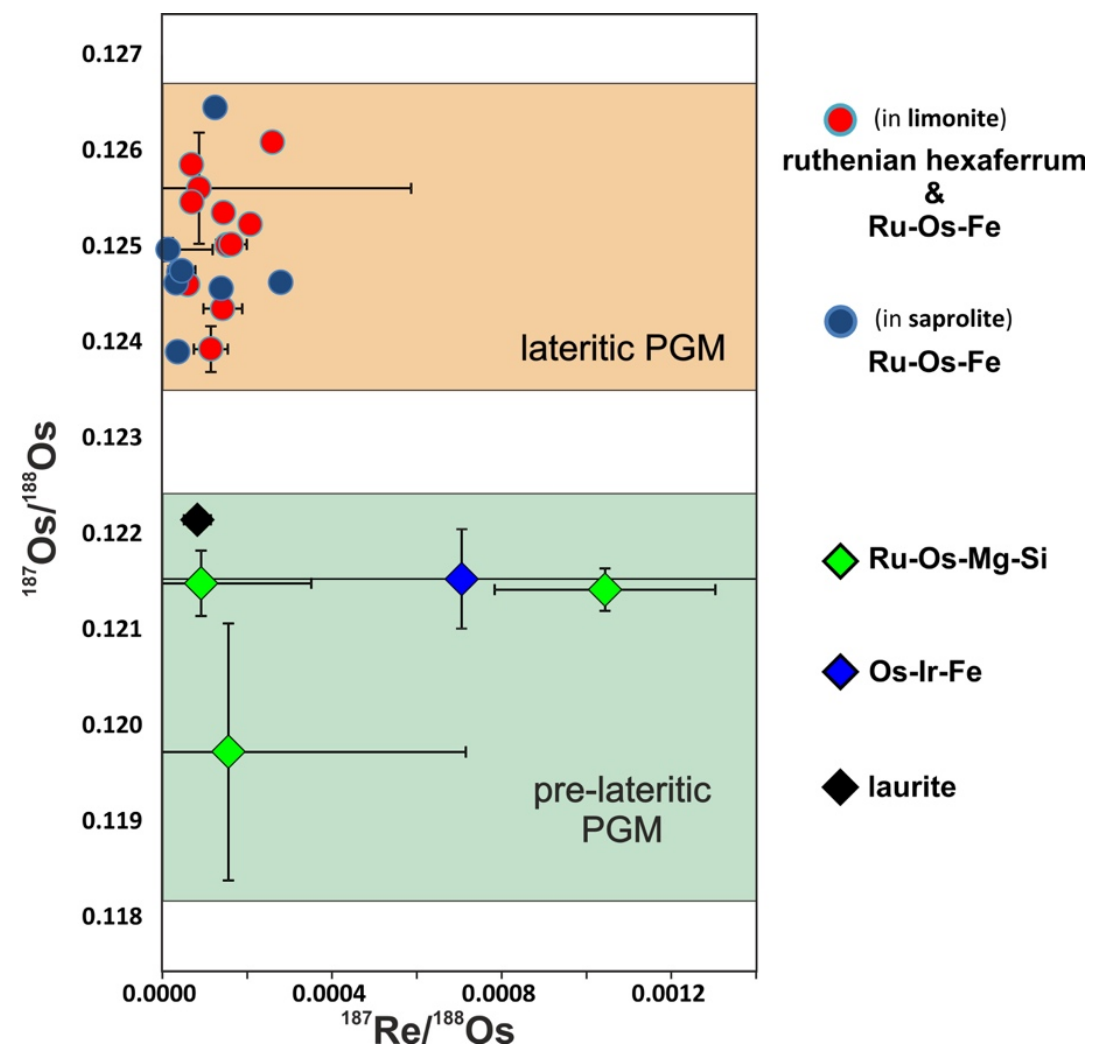

Figure 2. ${ }^{187} \mathrm{Os} /{ }^{188} \mathrm{Os}$ and ${ }^{187} \mathrm{Re} /{ }^{188} \mathrm{Os}$ isotopic ratios for pre-lateritic and lateritic PGM from the Ni-laterite profile of the Falcondo mining area in the Dominican Republic.

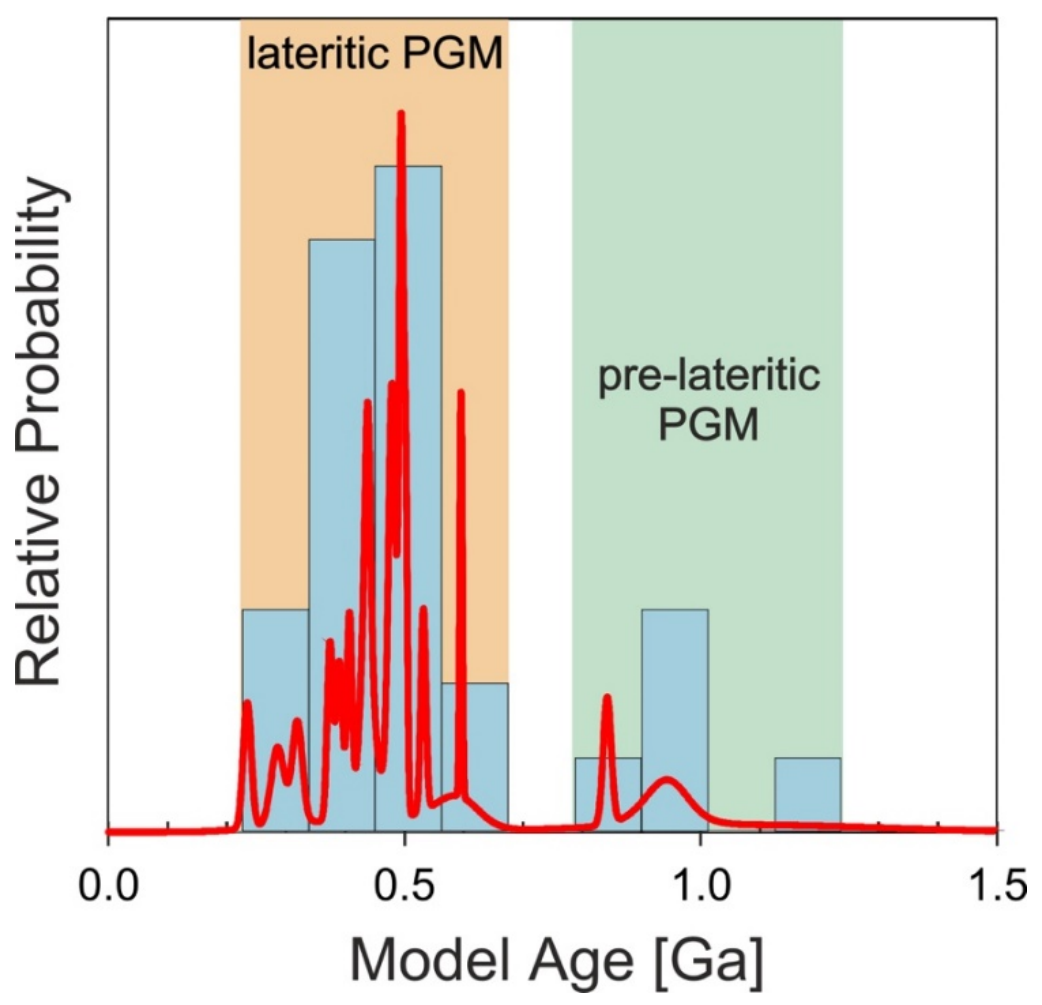

Figure 3. Cumulative probability plots and histograms (shaded bars, relative probability) of Os model ages from pre-lateritic and lateritic PGM analyzed in this study. 


\section{Discussion and Conclusions}

Grains of PGM now included within chromian spinel grains must have been precipitated from mantle-derived melts at the magmatic stage (i.e., $1200-1000{ }^{\circ} \mathrm{C}$; [16]). Their occurrence within unaltered chromian spinel suggests that these grains were not affected by post-magmatic alteration; hence, they should preserve the most pristine Os isotopic composition. Although our database is too small to be statistically robust, the observation that PGM formed by reworking of precursor magmatic PGM during serpentinization (i.e., Ru-Os-Mg-Si) yield similar ${ }^{187} \mathrm{Os} /{ }^{188} \mathrm{Os}$ (Figure 1; Table 1), leads us to suggest that no significant addition of crustal Os or Re to the magmatic PGM took place during serpentinization. This is consistent with previous observations that hydrothermal fluids involved in the low-temperature serpentinization of ultramafic rocks are not capable of mobilizing enough Os to cause secondary Os-isotope modification of individual grains $[4,5]$.

In contrast, the reaction of these high-temperature PGM with aqueous solutions under lateritic weathering conditions promoted their transformation to Ru-Os-Fe alloys with Ru-rich hexaferrum (i.e., ruthenian hexaferrum) as final product, containing microchannels of Fe oxide(s), mostly oxidized magnetite. These neoformed PGM are found in the highest part of the lateritic profile (Figure 1; [16]) and have higher, rather homogenous ${ }^{187} \mathrm{Os} /{ }^{188} \mathrm{Os}$ (note that Loma Larga and Loma Peguera are located $2.5 \mathrm{~km}$ from each other) than their precursor pre-lateritic PGM (note that lateritic and pre-lateritic PGM are present in the same sample from Loma Peguera), suggesting an open-system behavior of the Re-Os system during advanced stages of laterization. We ruled out the possibility that this disturbance of the Re-Os system was produced by Re loss from the precursor high-temperature PGM because of their very low (nearly zero) ${ }^{187} \mathrm{Re} /{ }^{188} \mathrm{Os}$ as is seen in many PGM from ophiolites worldwide [23]. However, it is interesting to note that quantitative element maps of ruthenian hexaferrum reveal zones with strong depletion in Os which are correlated with higher Fe contents (i.e., more oxidized magnetite; Figure 4). This suggests that disturbance of the Re-Os system may be related to the precipitation of magnetite from Fe-rich oxidizing fluids carrying either radiogenic ${ }^{187} \mathrm{Os}$, or parent ${ }^{187} \mathrm{Re}$ that would produce common ${ }^{187}$ Os by its decay ingrowth, although this is less likely since the maximum laterite age is approximately $105 \mathrm{Ma}$. The precipitation of this magnetite along micro-channels in RuOs-Fe grains counterbalanced the Os loss [16,24]. Interestingly, the authors of [8] reported that in placers from Oregon in USA, Os-Ir-Ru alloys with Fe-rich lamellae (probably magnetite) exhibit higher ${ }^{187} \mathrm{Os} /{ }^{188} \mathrm{Os}$ ratios than homogenous Os-Ir-Ru. Likewise, the infiltration of Fe-rich meteoric waters has previously been suggested to explain the Osisotope compositions of some iron formations [21]. These authors provided isotopic evidence for extensive exchange between Os and $\mathrm{Fe}$ in the ores via the precipitation of supergene magnetite.

The observations above clearly are in disagreement with previous studies suggesting that the Re-Os system in Os-rich PGM remains unchanged $[6,7,9,10,25]$. The differences between high-temperature and lateritic PGM in the Ni-rich laterites from Falcondo led us to speculate that a significant part of the Os-isotopic heterogeneity described in many placer PGM, and interpreted to be mantle-derived, may be actually due to post-magmatic disturbance by low-temperature fluids. As observed in the Ni-rich laterite from Falcondo, lateritic PGM analyzed in this study yield ${ }^{187} \mathrm{Os} /{ }^{188} \mathrm{Os}$ within the range of present-day mantle materials (0.1290; see [22]), which suggest that their ${ }^{187}$ Os $/{ }^{188}$ Os now reflects the mixing of ${ }^{187}$ Os derived from continental- and mantle-like sources but it is difficult to determine the contribution of each one. If mixing of ${ }^{187} \mathrm{Os}$ from different sources is involved in the transformation process of lateritic PGM then model ages cannot be used. An open-system alteration of Os-rich PGM during supergene processes as we observed would result in modification of the ${ }^{187} \mathrm{Os} /{ }^{188} \mathrm{Os}$ ratios, producing meaningless values for initial ${ }^{187} \mathrm{Os} /{ }^{188} \mathrm{Os}$ and model ages (Figure 3). Therefore, interpretations of mantle events based on the analysis of PGM nuggets from placers may have to be re-evaluated. Our observations also provide further evidence for PGE mobility in low-temperature systems. 
The Re-Os isotope data provide additional constraints on the in situ neoformation of PGM in the supergene environment [14-16].
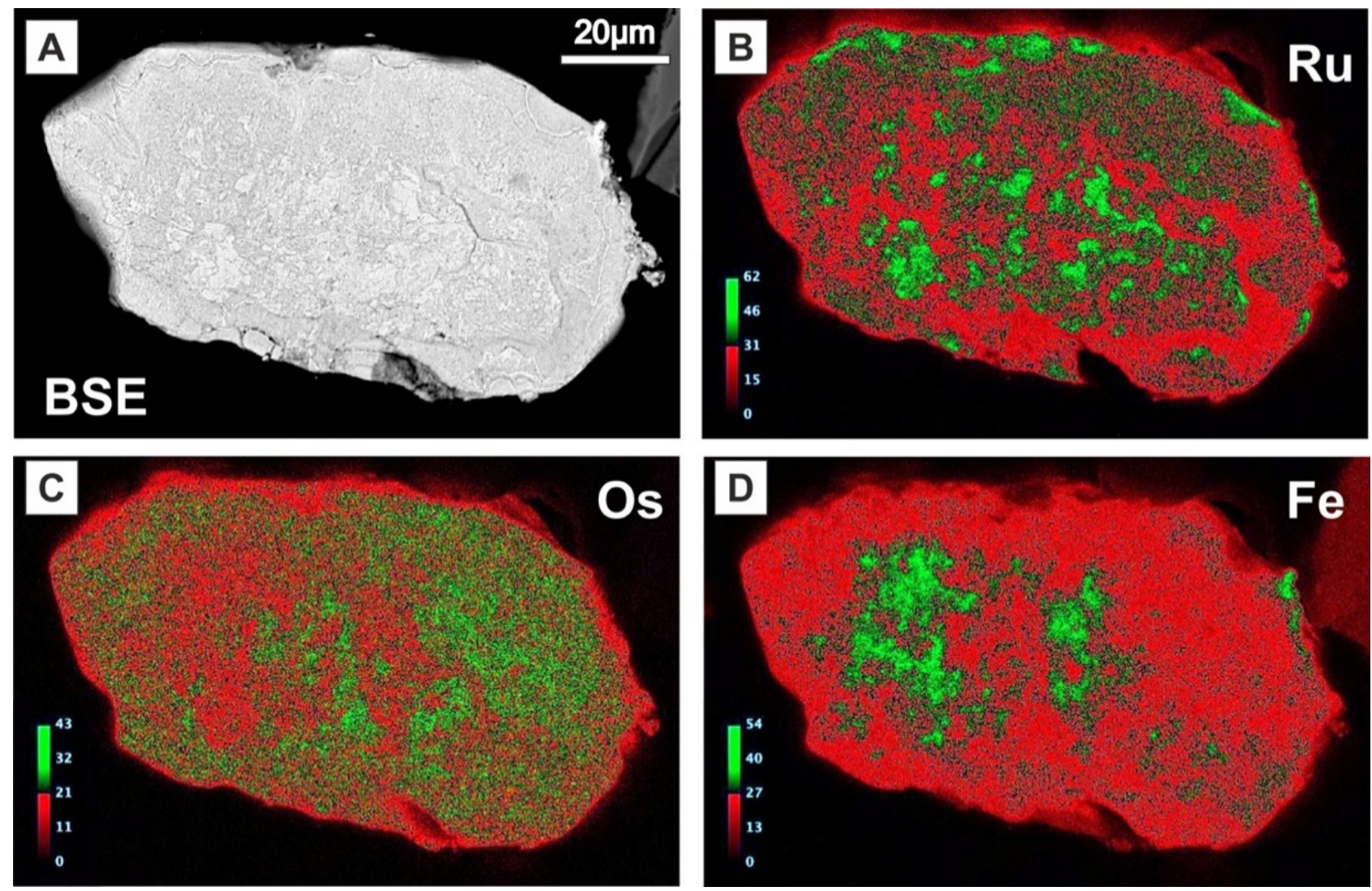

Figure 4. Quantitative EPMA element distribution maps (in $w \mathrm{t} \%$ ) of a typical ruthenian hexaferrum grain from the limonite horizon of the Falcondo Ni-laterite mine in the Dominican Republic. Note the negative correlation between Os and Fe: (A) back-scattered electron (BSE) image; (B-D) quantitative element maps for Ru, Os and Fe, respectively.

Author Contributions: By discussing the data, interpreting the results and reviewing the manuscript. More specifically, T.A. carried out the PGM separation, EMPA and SEM analytical work. In situ LA-MC-ICPMS analysis was carried out by J.M.G.-J. at GEMOC under the supervision of W.L.G. The initial manuscript draft was written by T.A., J.M.G.-J. and J.A.P. and subsequently improved after receiving the reviews from S.G., F.L., W.L.G. and S.Y.O. All authors have read and agreed to the published version of the manuscript.

Funding: This research was financially supported by FEDER Funds and the following Spanish Projects: PID2019-105625RB-C21 and RTI2018-099157-A-I00 granted by the "Ministerio de Ciencia, Innovación y Universidades" to JAP and JMGJ, respectively. Additional funding was provided by the Ramón y Cajal Fellowship RYC-2015-17596 to JMGJ. This is also a contribution from the ARC National Key Centre for Geochemical Evolution and Metallogeny of Continents (www.gemoc.mq.edu.au) and the ARC Centre of Excellence for Core to Crust Fluid Systems (www.ccfs.mq.edu.au). TA was supported by the Centre of Advanced Mining and Metallurgy (CAMM; www.ltu.se/centres/o/camm).

Data Availability Statement: The data is shown in the table of the article.

Acknowledgments: The authors gratefully acknowledge the help and hospitality extended by the staff of Falcondo mine. Excellent technical support during EPMA sessions by X. Llovet and during FESEM sessions by Eva Prats at the Serveis Científics i Tecnòlogics (University of Barcelona) is highly appreciated. Louis J. Cabri and Vladimir Rudashevsky are thanked for their help during installation of the HS-11 laboratory in Barcelona. A special thanks goes to three anonymous reviewers, to Laurie Reisberg, to James M.D. Day and to Kreshimir N. Malitch for their critical and detailed reviews.

Conflicts of Interest: The authors declare no conflict of interest. 


\section{References}

1. Carlson, R.W. Application of the Pt-Re-Os isotopic systems to mantle geochemistry and geochronology. Lithos 2015, 82, 249-272. [CrossRef]

2. Shi, R.; Alard, O.; Zhi, X.; O'Reilly, S.Y.; Pearson, N.J.; Griffin, W.L.; Zhang, M.; Chen, X. Multiple events in the Neo-Tethyan oceanic upper mantle: Evidence from Ru-Os-Ir alloys in the Luobusa and Dongqiao ophiolitic podiform chromitites, Tibet. Earth Planet. Sci. Lett. 2007, 261, 33-48. [CrossRef]

3. González-Jiménez, J.M.; Gervilla, F.; Griffin, W.L.; Proenza, J.A.; Augé, T.; O’Reilly, S.Y.; Pearson, N.J. Os-isotope variability within sulfides from podiform chromitites. Chem. Geol. 2012, 291, 224-235. [CrossRef]

4. González-Jiménez, J.M.; Griffin, W.L.; Gervilla, F.; Kerestedjian, T.N.; O’Reilly, S.Y.; Proenza, J.A.; Pearson, N.J.; Sergeeva, I. Metamorphism disturbs the Re-Os signatures of platinum-group minerals in ophiolite chromitites. Geology 2012, 40, 659-662. [CrossRef]

5. Badanina, I.Y.; Malitch, K.N.; Lord, R.A.; Belousova, E.A.; Meisel, T.C. Closed-system behaviour of the Re-Os isotope system recorded in primary and secondary platinum-group mineral assemblages: Evidence from a mantle chromitite at Harold's Grave (Shetland ophiolite complex, Scotland). Ore Geol. Rev. 2015, 75, 174-185. [CrossRef]

6. Hattori, K.; Hart, S.R. Osmium-isotope ratios of platinum-group minerals associated with ultramafic intrusions: Os-isotopic evolution of the oceanic mantle. Earth Planet. Sci. Lett. 1991, 107, 499-514. [CrossRef]

7. Malitch, K.N. Osmium isotope constraints on contrasting sources and prolonged melting in the Proterozoic upper mantle: Evidence from ophiolitic Ru-Os sulfides and Ru-Os-Ir alloys. Chem. Geol. 2004, 208, 157-173. [CrossRef]

8. Walker, R.J.; Brandon, A.D.; Bird, J.M.; Piccoli, P.M.; McDonough, W.F.; Ash, R.D. 187Os-186Os systematics of Os-Ir-Ru alloy grains from southwestern Oregon. Earth Planet. Sci. Lett. 2005, 230, 211-226. [CrossRef]

9. Brandon, A.D.; Walker, R.J.; Puchtel, I.S. Platinum-osmium isotope evolution of the Earth's mantle: Constraints from chondrites and Os-rich alloys. Geochim. Cosmochim. Acta 2006, 70, 2093-2103. [CrossRef]

10. Pearson, D.G.; Parman, S.W.; Nowell, G.M. A link between large mantle melting events and continent growth seen in osmium isotopes. Nature 2007, 449, 202-205. [CrossRef]

11. Augusthitis, S.S. Mineralogical and geochemical studies of the platiniferous dunite-birbirite-pyroxenite complex of Yubdo, Birbir, W. Ethiopia. Chem. Erde 1965, 24, 159-196.

12. Stumpfl, E.F. The genesis of platinum deposits: Further thoughts. Miner. Sci. Eng. 1974, 6, 120-141.

13. Bowles, J.F.W. The development of platinum-group minerals in laterites. Econ. Geol. 1986, 81, 1278-1285. [CrossRef]

14. Aiglsperger, T.; Proenza, J.A.; Zaccarini, F.; Lewis, J.F.; Garuti, G.; Labrador, M.; Longo, F. Platinum group minerals (PGM) in the Falcondo Ni-laterite deposit, Loma Caribe peridotite (Dominican Republic). Miner. Depos. 2015, 50, 105-123. [CrossRef]

15. Aiglsperger, T.; Proenza, J.A.; Font-Bardia, M.; Baurier-Amat, S.; Galí, S.; Lewis, J.F.; Longo, F. Supergene neoformation of Pt-Ir-Fe-Ni alloys: Multistage grains explain nugget formation in Ni-laterites. Miner. Depos. 2017, 52, 1069-1083. [CrossRef]

16. Aiglsperger, T.; Proenza, J.A.; Galí, S.; Rius, J.; Longo, F.; Domènech, C. The supergene origin of Ruthenian Hexaferrum in Ni-laterites. Terra Nova 2017, 29, 106-116. [CrossRef]

17. Aiglsperger, T.; Proenza, J.A.; González-Jiménez, J.M.; Galí, S.; Longo, F.; Griffin, W.L.; O’ Reilly, S.Y. Osmium isotope characteristics of primary and secondary PGM in Ni-laterites. Macla 2015, 20, 19-20.

18. Pearson, N.J.; Alard, O.; Griffin, W.L.; Jackson, S.E.; O’Reilly, S.Y. In situ measurement of Re-Os isotopes in mantle sulfides by laser ablation multicollector-inductively coupled plasma mass spectrometry: Analytical methods and preliminary results. Geochim. Cosmochim. Acta 2002, 66, 1037-1050. [CrossRef]

19. Lewis, J.F.; Draper, G.; Proenza, J.A.; Espaillat, J.; Jiménez, J. Ophiolite-related ultramafic rocks (serpentinites) in the Caribbean region: A review of their occurrence, composition, origin, emplacement and nickel laterite soils. Geol. Acta 2006, 4, $237-263$. [CrossRef]

20. Villanova-de-Benavent, C.; Proenza, J.A.; Galí, S.; García-Casco, A.; Tauler, E.; Lewis, J.F.; Longo, F. Garnierites and garnierites: Textures, mineralogy and geochemistry of garnierites in the Falcondo Ni-laterite deposit, Dominican Republic. Ore Geol. Rev. 2014, 58, 91-109. [CrossRef]

21. Ripley, E.M.; Shafer, P.; Li, C.; Hauck, S.A. Re-Os and O isotopic variations in magnetite from the contact zone of the Duluth Complex and the Biwabik Iron Formation, northeastern Minnesota. Chem. Geol. 2008, 249, 213-226. [CrossRef]

22. Walker, R.J.; Horan, M.F.; Morgan, J.W.; Becker, H.; Grossman, J.N.; Rubin, A.E. Comparative ${ }^{187}$ Re- $-{ }^{187}$ Os systematics of chondrites: Implications regarding early solar system processes. Geochim. Cosmochim. Acta 2002, 66, 4187-4201. [CrossRef]

23. O’Driscoll, B.; González-Jiménez, J.M. Petrogenesis of the Platinum-Group Minerals. Rev. Mineral. Geochem. 2016, 81, 489-578. [CrossRef]

24. Jiménez-Franco, A.; González-Jiménez, J.M.; Roqué, J.; Proenza, J.A.; Gervilla, F.; Nieto, F. Nanoscale constraints on the in situ transformation of Ru-Os-Ir sulfides to alloys at low temperatura. Ore Geol. Rev. 2020, 124, 103640. [CrossRef]

25. Pašava, J.; Malec, J.; Griffin, W.L.; González-Jiménez, R.M. Re-Os isotopic constraints on the source of platinum-group minerals (PGMs) from the Vestřev pyrope-rich garnet placer deposit, Bohemian Massif. Ore Geol. Rev. 2015, 68, 117-126. [CrossRef] 